\title{
Factors To Influence Employee Performance In Bank Tabungan Negara Sharia Semarang
}

\author{
Afita Puji Ilahi' ${ }^{1}$, Arif Afendi \\ 1,2Universitas Islam Negeri Walisongo Semarang, Indonesia \\ puji_vita@yahoo.co.id
}

\begin{abstract}
Purpose - This research aimed to know the analysis of the influence of work experience, education, and work motivation on the employees' performance of BTN Syariah KCS Semarang.

Method - This research used primary data namely questionnaire which used Likert scale as the calculation scale, and also documentation given by the employees' of BTN Syariah KCS Semarang. The samples of this research were 73 employees'. To analyse the data, the writer used multiple linier regression method and SPSS 16 version.

Result - The result of the research showed that work experience had positive and significant effect toward employees' performance, education had positive and significant effect toward employees' performance, and work motivation had positive but nit significant effect toward employees' performance. It showed that work experience, education, and work motivation had positive and significant effect toward employees' performance.

Implication - This study uses the data from only one Islamic bank.

Originality - The paper looks into the determinant factors ofemployees' performance at BTN Syariah Semarang. Previous studies have only focused on employees' performance in conventional banks. On the other hand, this paper contributes to the empirical literature, giving a clearer picture of the determinants of employees' performance of Islamic banks.
\end{abstract}

Keywords: $\quad$ work experience; education; work motivation; employees' performance 
Afita Puji llahi, Arif Afendi

\section{Introduction}

Islam is a universal religionto regulate all aspects of life, especially in economics. This becomes the main point of economic development. One of the Islam economic foundations today is the Islamic financial institutions, especially in Islamic banking.

Islamic banking is an Islamic financial institution that is engaged in services using Islamic legal principles. Islamic banking in Indonesia continues to grow. It became a standard development success of its existence.

The development of sharia banking in the reform era was marked by the approval of Law No.10 of 1998. The Act stipulates details on the legal basis and types of businesses that can be operated and implemented by Islamic banks. The Act also provides direction for Conventional Banks to open sharia branches or even change themselves as a whole into sharia banks.

inadequate human resources (HR) that affect the performance of sharia financial transactions that often inaccurate. This is due to the lack of academic institutions and training of Islamic banking so that to obtain professional and educated personnel of Islamic banking is very difficult. Of course, this condition greatly affects the productivity and professionalism of Islamic banking itself.

The quality of human resources in organizations is a very important role to achieve sharia bank standards. Within the organization of sharia, banking organizations must take various methods to obtain high-quality human resources, productive performance, skills, creativity, professionalism, discipline, mastering, and in developing the technology.

To hire good human resources is not easy, there are still many human resources who have not mastered the skills and expertise in their fields, therefore human resources who have sufficient experience will help organizations develop rapidly. Work experience is a step to carry out the work according to their abilities and in the placement of an effort to create efficiency and effectiveness of employees to obtain optimal human resources for the company. 
A person's ability factor is not enough just in terms of education and training, but can also be seen in terms of one's work experience while working in a particular company or organization. Experience in work by itself can improve workability because the more variations in work and the more intensive the work experience obtained.

Apart from work experience, one of the efforts to have adequate human resources in education, because one's education will affect the mindset, attitude of the HR and the behavior of the HR. So that human resources will join the company can make a major contribution to the company. In other words, a major contribution is the ability to work or manage the activity of employees to provide better services in the enterprise. With the expectation of this contribution, a company is required to strive to improve the performance of $\mathrm{HR}$ by providing various directions so that $\mathrm{HR}$ is stimulated to improve the quality of work produced. Therefore, education has an important enough role in human resources to live a better life. In addition to the large contribution, HR working in the sharia banking sector is also still dominated by HR who have non-sharia education, for that sharia banking needs to improve the quality of human resources in addition to other improvements such as product and service improvements.

According to Euis Amalia (2012), Human Resources working in the Islamic finance sector is still dominated by their background in conventional (90\%) and is equipped by a short training Islamic banking. Only about $10 \%$ background sharia. This fact certainly shows the influence on the quality of the existing "sharia" industry. That fact still applies in the current year.

From the description above to achieve the company's development goals in the form of Islamic banking, it is necessary to have policies in developing human resources to be able to foster a sense of accountability of employees to the company by recruiting employees who have good performance. Performance is defined as an achievement of certain job requirements that ultimately are directly reflected in the output produced both quantity and quality. 
Afita Puji llahi, Arif Afendi

Performance is also often described as integrity, hard work, perseverance, and others. Improving performance is one form of employee accountability to the company. Therefore, every individual or group in the company must have good performance and awareness to cooperate and be able to support the interests of the company's strategy to be able to support all the needs of the company.

Assessment of the implementation of the work carried out employees or often referred to as a performance assessment or performance appraisal is also necessary to see the extent of the employee's performance in carrying out its responsibilities which of course refers to a system of formal and structured used as an instrument to measure, assess and provide workrelated traits, control employee behavior, including attendance rates, work results for making decisions relating to salary increases, bonus giving, promotions and employee placement in positions in accordance with the fields he knows.

Employees who have high performance are employees who are talented, qualified, highly motivated, and willing to work together in a team. Therefore, a leader or manager must be able to set work goals for employees to produce high-quality, highly motivated, and productive employees.

Motivation is one way to create good employee performance apart from work experience and education. Many things can be done by a leader or manager to motivate their employees, such as meeting the needs of employees, allowing them to submit ideas in the decision making process, giving awards and recognition of their work performance. After employees get high motivation, their morale will get higher so that they can achieve what the company expects. The company will give an appreciation of the work that has been achieved by employees so that employees will get satisfaction for what they have achieved from the results of their work.

As several previous studies examined each variable work experience, education, and work motivation on employee performance. Among the variables that work experience, according to research Diniaty and Fairuz 
(2014), research results say that the work experience has a positive effect on employee performance, which means more work experience possessed by a person, the better the performance. Because work experience is obtained from employees who already have more working hours which are expected to have a resolution of various kinds of problems that exist in the world of work, by the individual abilities of each employee.

Based on the results of Miranti's research et al (2016) states that education has a positive influence on employee performance which means the better and higher a person's education, the better the performance will be. Because education can describe how much influence on attitudes and behavior in individual development and in carrying out activities.Besides education is one of the social forces that are formed and built the human future by itself. so that in the end education also influences employee performance.

According to Slamet Riyadi (2011), the results of his research stated that work motivation has a positive effect on employee performance, meaning that the higher the work motivation of a person, the better the performance. According to him, motivation itself is the most determining factor for an employee at work. Although the ability of the maximum employee is accompanied by adequate facilities, but if there is no motivation to do the work, the work will not run as expected.

Based on the background above, the formulation in this study is to find out whether work experience, education, and work motivation affect the performance of KCS Islamic Bank Semarang employees. While the purpose of this study is to examine whether work experience, education, and work motivation affect the performance of KCS Islamic Bank Semarang employees.

\section{Literature Review}

\section{Work Experience}

According to Trijoko, quoted by Purwanto \& Hermani DS (2017) states that work experience is knowledge or skills that have been known and 
Afita Puji Ilahi, Arif Afendi

mastered by someone who results from actions or work that has been done for a certain amount of time. With the experience gained someone will be more capable and skilled and able to carry out their work duties.

The objectives of work experience are: 1) Get as many workers as possible and add work experience in various fields. 2) Preventing and reducing work competition that often arises among the workforce.

According to Bill Foster, quoted by Ayuk Wahdanfiari Adiba (2014) there are also several things to determine whether an employee is experienced in working, which is also an indicator of work experience, namely: long time / period of work; level of knowledge and skills possessed; mastery of work and equipment; type of work.

\section{Education}

According to Andrew E. Sikula in Mangkunegara (2009) states that education is a long-term process that uses systematic and organized procedures, in which managerial labor learns conceptual and theoretical knowledge for general purposes.

According Suhardjo cited by Miranti et al (2016) in his research stated that the level of education is the stage of education that is determined based on the level of development of students, the objectives to be achieved and the will developed. The level of education affects the changes in attitudes and behavior in healthy living. Higher education level will make it easier for someone or the community to absorb information and implement it in their daily behavior and lifestyle.

According to Simamora, quoted by Vera Nitta Turure (2013), education is divided into two types. 1) Public education is education carried out inside and outside of school, both organized by the government and the private sector, with the aim of preparing and working for educational participants to obtain general knowledge. 2) Vocational education is public education planned to make preparations for the participants of education and carry out the work in accordance with the vocational field. 
Factors To Influence Employee Performance ...

According to Mangkunegara (2009) quoted by Dedy Syufriadi, the indicators of the education variables are as follows: educational background; insight; the important role of education; application at work; improved work performance

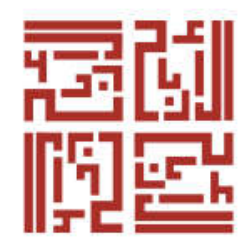

\section{Work Motivation}

According to Mangkunegara (2017) motivation comes from the word motive which means an impulse of needs within the employee that needs to be met so that the employee can adjust to his environment, while motivation itself is a condition that moves employees to be able to achieve the goals of the motive.

According to Rivai, quoted by M. Kadarisman in the book (2012), Motivation is a series of attitudes and values that influence individuals to achieve specific things in accordance with individual goals. That attitude and value is an invisible that gives strength to encourage individuals to behave in achieving goals.

According to Abraham Maslow quoted by Anwar Prabu Mangkunegara (2017), the hierarchy of human needs is: 1) The need physiology are basic needs such as food, water, shelter and rest. This need is a low level requirement or also called a basic need. 2) The need for a sense of security as the need for protection from threat, danger, conflicts and the environment. 3) The need to feel ownership (socialization) is the need to be accepted by groups, affiliated, giving and receiving love, and friendship. 4) The need for self-esteem such as the need to be respected, and valued by others. 5) The need to actualize oneself, is the need to use abilities, skills and potential. The need to argue by presenting ideas provides criticism and evaluation of something.

According to McCelland, quoted by Anwar Prabu Mangkunegara (2017), there are 3 types of human needs that are indicators of work motivation including: 1) Need for Achievement is the need for achievement which is a reflection of the drive for responsibility for problem-solving. The need for achievement is the need to do a better job than before, always desiring to 
Afita Puji Ilahi, Arif Afendi

achieve higher achievements. 2) Need for Affiliation is the urge to interact with others, not wanting to do something detrimental to others. 3) Need for Power is the need for power which is a reflection of the drive to achieve authority to influence others.

\section{Employee Performance}

According to Anwar Prabu Mangkunegara (2017) employee performance is the result of the quality and quantity of work achieved by an employee in carrying out their duties in accordance with the responsibilities given to him.

According to Handoko, quoted by Andiyanto and Darmastuti (2011) states that performance is a pleasant or unpleasant emotional state. This will be seen from the positive attitude of employees towards everything that is encountered in the work environment.

According to Anwar Prabu Mangkunegara (2017) stated that the performance indicators, is: 1) Quality, Quality of work is how well an employee does what should be done. 2) Quantity The quantity of work is how long an employee works in one day. This work quantity can be seen from the speed of work of each employee respectively. 3) Implementation of tasks, Task Implementation is how far the employee is able to do his job accurately or there are no mistakes. 4) Responsibility, Responsibility for work is an awareness of the obligations of employees to carry out work provided by the company.

\section{Methods}

\section{Types of Research}

This type of research used field research with a quantitative approach. Data sources were from primary data and collecting data by observation, interview, and questionnaires that were measured with a Likert scale. 
Factors To Influence Employee Performance ...

\section{Population and Sample}

The population was from the subject of research. The population in this study were all employees of BTN Syariah KCS Semarang. While the sample of participants was 73 employees at BTN Syariah KCS Semarang. The sampling technique in this study used the technique of taking saturated samples, where the determination of the sample was done when all members of the population used as sample samples.

\section{Hypothesis}

According to research Diniaty and Fairuz (2004) mentions that the variable work experience has a positive effect on employee performance. This shows that the longer a person works in a particular field, the more work experience he will get. This means that with long enough experience and many it is expected that an employee will have better abilities than employees who do not have much experience.

$\mathrm{H}_{1}=$ Work experience has a positive effect on employee performance.

Education is a very important factor in developing human resources. Direct education can add insights into thinking and behaviour patterns to be better every day. According to Maria Asti Andhanari (2005) and Miranti (2016) states that education has a positive effect on employee performance. The higher the education of employees, the higher the expected human resources will be. With an increase in the level of education, it will be followed by significantly improving employee performance.

$\mathrm{H}_{2}=$ Education has a positive effect on employee performance. 
Afita Puji Ilahi, Arif Afendi

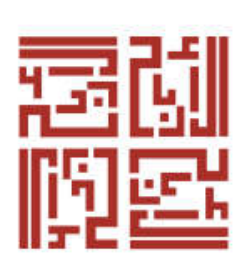

AL-ARBAH | 10

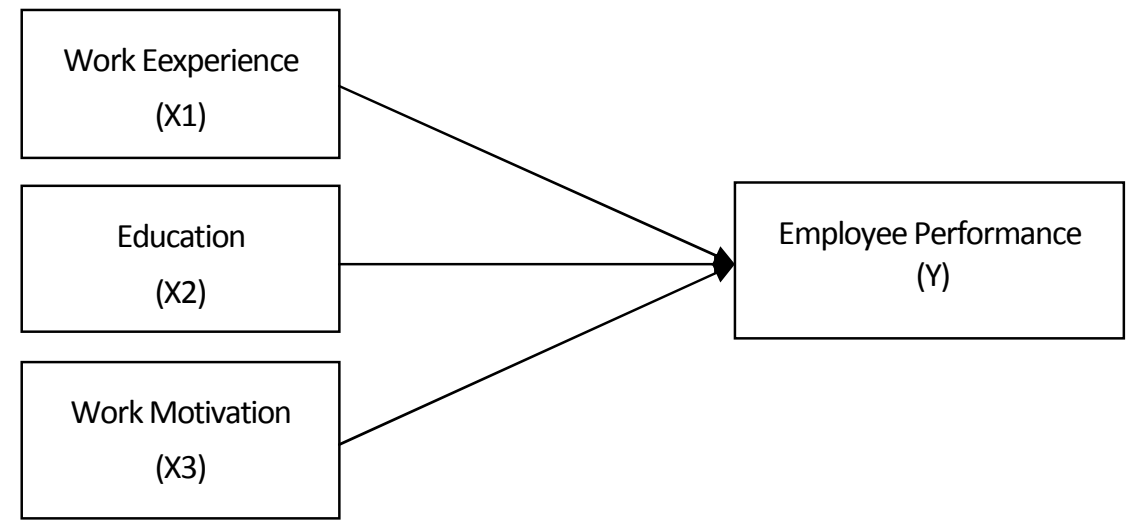

Figure 1. Research Framework

Motivation is a growing urge of the individual to achieve the desired thing. Motivation comes from an employee himself for the needs that make him motivated to be more diligent in doing his work, or motivation is obtained from others (managers, friends, subordinates) which requires an employee to work even harder to achieve good results.

According to Slamet Riyadi (2011) and Miranti (2016) states that work motivation has a positive effect on employee performance. With an increase in motivation to work, then it will be followed by an increase in the performance of employees in other words, the more a person is motivated to do the job then the performance will increase.

Based on the description above, the following conclusions can be drawn:

$\mathrm{H}_{3}=$ Work motivation has a positive effect on employee performance.

\section{Results and Discussion}

\section{Descriptive Statistics}

Table 1 about descriptive statistic. The table 1 explaining that the work experience variable minimum answers 4 respondents and a maximum of 20, with an average total minimum answer of 14.41 and a standard deviation of 3.395 . 
Factors To Influence Employee Performance ...

Tabel 1. Descriptive Statistics

\begin{tabular}{cccccc}
\hline & N & Minimum & Maximum & Mean & Std. Deviation \\
\hline Work experience & 73 & 4 & 20 & 14.41 & 3.395 \\
Education & 73 & 6 & 23 & 18.18 & 3.293 \\
Work motivation & 73 & 7 & 15 & 11.15 & 1.737 \\
Employee performance & 73 & 8 & 20 & 15.44 & 2.511 \\
Valid N (listwise) & 73 & & & & \\
\hline
\end{tabular}

Respondents' answers education variable minimum 6 and maximum of 23 , with an average total minimum answer $18: 18$ and a standard deviation of 3,293 . work motivation respondents' answers minimum 7 and maximum of 15 , with an average total minimum answer $11: 15$ and a standard deviation of 1.737. employee performance variables respondent answers minimum 8 and maximum of 20 , with an average total minimum answer 15:44 and a standard deviation of 2.511 .

\section{Classic Assumption Test}

\section{Normality test}

The normality test results can be seen through the following table:

Tabel 2. Normality Test One-Sample Kolmogorov-Smirnov Test

\begin{tabular}{ccc}
\hline & & Unstandardized Residual \\
\hline N & & 73 \\
Normal Parametersa & Mean & .0000000 \\
& Std. Deviation & 1.72832045 \\
Most Extreme Differences & Absolute & .064 \\
& Positive & .054 \\
& Negative & -.064 \\
Kolmogorov-Smirnov Z & & .547 \\
Asymp. Sig. (2-tailed) & & .926 \\
\hline
\end{tabular}

AL-ARBAH: Journal of Islamic Finance and Banking - Vol. 1 No. 1 (2019) 
Afita Puji llahi, Arif Afendi

From the table above the results of the Kolmogorov-Smirnov normality test can be found to be normally distributed. This is evidenced by the value (Asymp.Sig.2-tailed) on the variables of work experience, education, work motivation and employee performance greater than 0.05 ie $0.926>0.05$. Then it can be said that the data is normally distributed.

\section{Multicollinearity Test}

In the multicollinity test stated that the independent variables must be free from the symptoms of multicollinearity. Symptoms of multicollinearity are symptoms of correlation between dependent variables. This test aims to test whether the model in using regression found a correlation between independent variables. The basis for decision making is: 1) If the VIF value> 10 and tolerance $<0.1$, it can be concluded that in the regression equation there are multicollinearity problems. 2) If the VIF value $<10$ and Tolerance $>$ 0.1 , it can be concluded that in the regression equation there is no multicollinearity problem.

Based on the test results multikolinieritas Table 3 shows that the variable X1 (Work Experience) obtain VIF 1,534, X2 (Education) obtain VIF 1,418, and X3 (Work Motivation) scored 1,100. the results of the VIF values of the three variables are smaller than 10 . So it can be said that this study is free from the presence of multicollinearity.

Table 3. Multicollinearity Test Results Coefficients ${ }^{\mathrm{a}}$

\begin{tabular}{|c|c|c|c|c|c|c|c|}
\hline & \multirow[t]{2}{*}{ Model } & \multicolumn{2}{|c|}{$\begin{array}{l}\text { Unstandardized } \\
\text { Coefficients }\end{array}$} & \multirow[t]{2}{*}{$T$} & \multirow[t]{2}{*}{ Sig. } & \multicolumn{2}{|c|}{$\begin{array}{l}\text { Collinearity } \\
\text { Statistics }\end{array}$} \\
\hline & & B & Std. Error & & & Tolerance & VIF \\
\hline \multirow[t]{4}{*}{1} & (Constant) & 3.821 & 1.679 & 2.276 & .026 & & \\
\hline & Work experience & .159 & .076 & 2.092 & .040 & .652 & 1.534 \\
\hline & Education & .428 & .075 & 5.691 & .000 & .705 & 1.418 \\
\hline & Work motivation & .138 & .126 & 1.102 & .274 & .909 & 1.100 \\
\hline
\end{tabular}


Factors To Influence Employee Performance ...

\section{Heterokedastisitas}

Heterokesdastisitas test is used to determine whether or not the classic assumption deviation heteroskedastisitas namely inequality variants of residuals for all observations in the regression model. A good regression model should not occur heterokedastisitas.

To test heterocedasticity, in this study the Glejser test was used by regressing the absolute residual value of the independent variable. If the significant count is greater than alpha $=5 \%$, then there is no heterokedasticity problem. However, if the significant value is less than alpha $=5 \%$, it can be concluded that the regression model occurs heterokedastisitas. The existence of heterokedasticity can be known by looking at the plot graph between the prediction of the dependent variable (ZPRED) and the residual (ZRESID).

Based on table 4 the heterokedasticity test results show that the significance value of variable X1 (Work Experience) is 0.326 , variable X2 (Education) is 0.954 , and variable X3 (Work Motivation) is 0.701. From each variable has a significant value of more than 0.05 , it can be said that this study does not have heterokedastisitas.

Table 4. Heteroscedasticity Test Results Coefficients ${ }^{a}$

\begin{tabular}{ccccccc} 
& \multicolumn{7}{c}{$\begin{array}{c}\text { Unstandardized } \\
\text { Coefficients }\end{array}$} & $\begin{array}{c}\text { Standardized } \\
\text { Coefficients }\end{array}$ & & \\
& Model & B & Std. Error & Beta & $\mathbf{t}$ & Sig. \\
\hline $\mathbf{1} \quad$ (Constant) & 2.364 & .934 & & 2.530 & .014 \\
& & & & & -.989 & .326 \\
& Work Experience & -.042 & .042 & -.145 & -.989 & .954 \\
& Education & -.002 & .042 & -.008 & -.058 & .701 \\
\hline
\end{tabular}

a. Dependent Variable: Abs_Res 
Afita Puji llahi, Arif Afendi

\section{Multiple Linear Regression Analysis}

Table 5. Multiple Linear Regression Test Results Coefficients ${ }^{a}$

\begin{tabular}{cccccc}
\hline \multicolumn{7}{c}{ Unstandardized Coefficients } \\
& Model & B & Std. Error & $\mathbf{t}$ & Sig. \\
\hline 1 & (Constant) & 3.821 & 1.679 & 2.276 & .026 \\
& Work Experience & .159 & .076 & 2.092 & .040 \\
& Education & .428 & .075 & 5.691 & .000 \\
& Work Motivation & .138 & .126 & 1.102 & .274 \\
\hline
\end{tabular}

Based on Table 5 above, the multiple linear regression equation is as follows:

$$
\mathrm{Y}=3.821+0,159 \mathrm{X} 1+0,428 \mathrm{X} 2+0,138 \mathrm{X} 3+\mathrm{e}
$$

\section{Discussion}

\section{Effect of Work Experience on Employee Performance}

Based on the processed statistics in the multiple linear regression test it can be seen the value of the T test statistic with a t-test value of 2.092 while the t-table value of 1997, it can be concluded that the t-test of $2.092>1.997$ and the significant value is 0.040 , where the significance value is smaller than 0.5. It can be said that the relationship of work experience with employee performance has a positive and significant direction so that every time there is an increase in work experience will improve employee performance. Therefore, this hypothesis is accepted.

The results of this study are consistent with research conducted by Diniaty and Fairus (2014) and Octavianus and Adolfina (2018) research which shows that work experience has a positive and significant effect on employee performance. This means that the more work experience a person has, the better the performance will be, because work experience is gained by employees who have more working hours which are expected to have a 
variety of problems in the workforce, according to the individual abilities of each employee.

\section{The Effect of Education on Employee Performance}

Based on the results of statistical processing in the multiple linear regression test it can be seen the value of the statistical test $\mathrm{T}$ with a calculated value of 5.691 while the value of t-table 1.997, it can be concluded that the t-test 5.691> 1.997 and the significant value is 0.000 , where the significance value is smaller than 0.05 . It can be said that the relationship of education with employee performance is positive and significant so that if there is an increase in the level of education it will improve employee performance. Therefore, this research hypothesis is accepted.

The results of this study are consistent with research conducted by Miranti et al (2016) as well as Diniaty and Fairus research with results that indicate that education has a positive and significant effect on employee performance. This means that the better and higher a person's education, the better his performance will be because education can illustrate the magnitude of the influence of attitudes and behaviors in full personal development and participation in working on activities.

\section{The Effect of Work Motivation on Employee Performance}

Based on the results of statistical processing in the multiple linear regression test it can be seen the value of the statistical test $\mathrm{T}$ with a calculated value of 1.102 while the value of t-table 1.997, it can be concluded that the t-count $1.102<1.997$ and the significant value is 0.274 , where the significance value is greater than 0.05 . It can be said that the relationship between work motivations with employee performance is positive but not significant. With this test the hypothesis is accepted.

The results of this study are by research conducted by Slamet Riyadi (2011) which states that work motivation has a positive effect on employee performance, meaning that the higher the motivation provided, the more performance will improve. So it can be said by giving motivation both directly 
Afita Puji llahi, Arif Afendi

and indirectly such as adequate facilities to employees can improve employee performance so that it is better and by motivating employees to develop their potential for the progress of BTN Syariah KCS Semarang.

Sulis Arifah (2018) added in her research also stated that work motivation had a positive but not significant effect on employee performance. This means that the higher the motivation given to someone, the higher the performance, but the resulting level of performance is not so optimal. So it can be said that there is encouragement given by a leader or colleague to achieve the specified targets are not balanced with the creativity of employees in accepting and practicing these encouragement to improve their performance. it is possible that the employee does not have the motivation to advance himself let alone has the motivation to advance a company, the employee works just to work.

\section{Overall Significance Test Parameter Model (Test F)}

Based on data from the Statistical if multiple linear regression can be seen the value of the test statistic F with F-count of 25549 with a probability value or significance level of 0.000 . Since the probability is less than $0.05(0.000$ $<0.05$ ), the regression model can be used to predict the performance of an employee or can be said of work experience, education and motivation to work together and significant influence on employee performance BTN Syariah KCS Semarang.

\section{Tabel 6. Uji F ANOVA}

Based on data from the Statistical if multiple linear regression can be seen the value of the test statistic F with F-count of 25549 with a probability value or significance level of 0.000 .

\begin{tabular}{ccccccc}
\hline & Model & Sum of Squares & Df & Mean Square & F & Sig. \\
\hline $\mathbf{1}$ & Regression & 238.902 & 3 & 79.634 & 25.549 & $.000 a$ \\
& Residual & 215.071 & 69 & 3.117 & & \\
& Total & 453.973 & 72 & & & \\
\hline
\end{tabular}


Factors To Influence Employee Performance ...

Tabel 7. Determination Coefficient Test Results Model Summary ${ }^{b}$

\begin{tabular}{ccccc}
\hline Model & R & R Square & Adjusted R Square & Std. Error of the Estimate \\
\hline 1 & $.725 a$ & .526 & .506 & 1.765 \\
\hline
\end{tabular}

Based on Tabel 6. data from the Statistical if multiple linear regression can be seen the value of the test statistic F with F-count of 25549 with a probability value or significance level of 0.000 . Since the probability is less than $0.05(0.000<0.05)$, the regression model can be used to predict the performance of an employee or can be said of work experience, education and motivation to work together and significant influence on employee performance BTN Syariah KCS Semarang.

\section{Determination Coefficient Test (R2)}

Based on table 7. the results of the coefficient of determination test can be seen that the Rquer (R2) of 0.526 or $52.6 \%$ which indicates that there is an influence of work experience, education and work motivation variables. While the rest is influenced by other variables not found in this study.

\section{Conclusion}

Based on the results of research and discussion conducted by researchers in the previous chapter about the effect of work experience, education and work motivation on the performance of BTN Syariah KCS Semarang employees, the following conclusions can be drawn: 1) Work experience has a positive and significant impact on the performance of BTN Syariah KCS Semarang employees, meaning that the more work experiences a person has, the better the performance will be. 2) Education has a positive and significant effect on the performance of BTN Syariah KCS Semarang employees, meaning that the better and higher a person's education, the better their performance will be. 3) Work motivation has a positive but not significant effect on the performance of BTN Syariah KCS Semarang employees, meaning that the higher the employee's work motivation, the better the performance will be. But work motivation is not a strategic performance factor for employees. 
Afita Puji Ilahi, Arif Afendi

\section{References}

Amalia, Euis. (2012). Potret Pendidikan Ekonomi Islam di Indonesia. Jurnal Ekonomi Islam.

Andiyanto,Wilhelmus dan Ismi Darmastuti. (2011). Pengaruh Motivasi Kerja Dan Kepemimpinan Terhadap Kinerja Pegawai Pada Badan Keluarga Berencana Dan Pemberdayaan Perempuan Kabupaten Manggarai Flores Nusa Tenggara Timur. Fakultas Ekonomi Universitas Diponegoro Semarang.

Antonio, Muhammad syafi'i.(2001).Bank Syariah dari Teori ke Praktek. Jakarta: Gema Insani Press.

Bili, Wanceslaus, Erwin Resmawan, dan Daud Kondorura. (2013). Pengaruh Pengalaman Kerja Terhadap Kinerja Pegawai Di Kantor Kecamatan Laham Kabupaten Mahakam Ulu. eJournal Pemerintahan Integrattif. Volume 6, Nomor 3.

Hasibuan SP, Malayu. (2016).Organisasi Dan Motivasi. Jakarta: PT Bumi Aksara.

Kadarisman, M. (2012). Manajemen Pengembangan Sumber daya Manusia. Jakarta: Rajawali pers.

Mangkunegara, A.A. Anwar Prabu. (2017). Manajemen Sumber Daya Manusia Perusahaan. Bandung: Remaja Rosdakarya.

Miranti, Erien, Herkulana, dan Yarlina Yacoub. (2016). Pengaruh Tingkat Pendidikan, Masa Kerja Dan Motivasi Kerja Terhadap Kinerja Karyawan. Program PascaSarjana Pendidikan Ekonomi. FKIP Universitas Tanjungpura Pontianak.

Rivai, Veitzal. (2009). Islamic Humen Capital dari Teori kepraktik Manajemen Sumber Daya Islamia. Jakarta: PT. Raja Grafindo Persada.

Riyadi, Slamet. (2011). Pengaruh Kompensasi Finansial, Gaya Kepemimpinan, dan Motivasi Kerja Terhadap Kinerja Karyawan pada Perusahaan Manufaktur di Jawa Timur. Jurnal manajemen dan kewirausahaan, 13 (1).

Robbins P Stephen. (2010). Manajemen. Jakarta: Erlangga.

Turure, Vera Nitta. (2013). Pengaruh Pendidikan Dan Pelatihan Terhadap Peningkatan Kinerja Karyawan Pada Balai Pelatihan Teknis Pertanian Kalasey. Jurnal EMBA, 1 (3). 